光ディスクに収納でき, 画像処理システムでレイアウ 卜, 拡大 /縮小, トリミング, 色変換, 階調変換など を行う.

カラーハードコピーは, 主に各工程での仕事が間違 いなく行われたかを確認する目的で利用され，ハード コピー装置としては, ディジタル信号から出力できる タイプの電子写真方式, 銀塩写真方式, 昇華転写方 式，インクジェット方式のものが使われる.

\section{5.むす び}

カラーハードコピーの印刷技術への応用は, 多くの 画像処理システムの中にコンピュータが導入されてい る現在，ますます広がってきており，種々の新しいコ ピーシステムが登場してきている。それらは, カラー 画像の処理法としては興味深いものが多いが, 画質に ついては不充分なものが多い，印刷会社においては， どうしても印刷物と比較することになる，その場合， 印刷物とどれくらい似ているか, 近いかがポイントと なり，人間が見てどう感じるかといった主観評価にな っている. しかし, 将来は数值化できる調子再現, 色 再現, 鮮鋭度, 解像性, 粒状度などの画質要因につい て検討し, 客観的に評価, 判定した結果が主観評価と 一致するようになるだろう.

今後のカラーハードコピーの動向としては, 電気信 号(ディジタル信号)から直接ハードコピーを作るシス テムに主流が移るのではないかと考えられ，ディジ夕 ル網版校正システムとして, 電子写真方式, 高感度フ
オトポリマーを使う方式，特殊レーザ露光用コーティ ング材を使う方式の 3 つのタイプのシステムが開発中 であるが，現存のシステムの中にも，もう少し画質が 良ければ，あるいは，もう少しランニングコストが下 がれば普及するのにといったものが沢山あるので, 印 刷技術へのカラーハーードコピーの応用が, 近い将来, 大きなマーケットに成長することは間違いないことで あろう。

$(1989$ 年 6 月 29 日受付)

\section{〔参 考 文 献〕}

1）大西：“ビデオと印刷”, 日印学・日写学, 写真と印刷に関す る講演会, pp. 9-14 (1982)

2）鎗田：“ハイビジョンの印刷への応用”, 日印学・日写学, 写 真と印刷记関する講演会, pp. 36-41 (1987)

3）鎗田：“高品質静止画入カシステム”, 昭 63 日印学第 81 回 秋期予稿集, pp. 26-29 (1988)

4）高橋：“色校正技術とその画像特性”，日印誌，24, 3, pp. 27 $-36(1987)$

5）二村：“銀塩写真方式カラーコピーシステム”, 日印学・日写 学, 写真と印刷に関する講演会, pp. 29-38 (1986)

6）木下, 芝木: “トータルスキャナ活用の実際”, 印刷情報, 2, pp. 2-10 (1989)

7）太田：“レイアウトスキャナシステム概論”，印刷雑誌，72, 3, pp. 39-45 (1989)

\begin{tabular}{|c|}
\hline 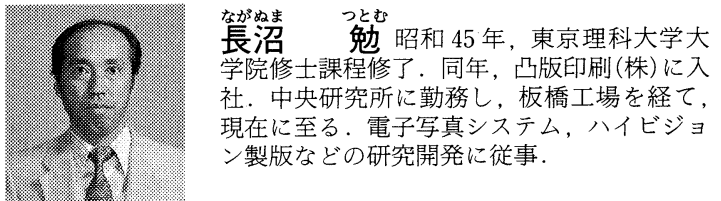 \\
\hline
\end{tabular}

\title{
4-3 テレビ画像の新聞写真への応用
}

\section{尾 形 貢 ${ }^{\dagger}$}

\section{1. まえがき}

近年, 新聞界は紙面のビジュアル化, 特にカラー写 真に傾注している．読者のニーズであり，業界の大き なテーマである，新聞は本来文字のメディアである が，いかに名文，美句で表現しても画の迫力はまた格 別である。世界各局を衛星で結んだ強力なテレビネッ トワーク，その取材網とスピードは，新聞のニュース

\footnotetext{
†社団法人共同通信社 名古屋支社 技術部

"4-3 Video Photo Convert for Press News" by Mitugu Ogata (Engineering Department of Kyodo News Service, Nagoya)
}

写真としてもしばしば威力を発揮する.

テレビ画像から静止画を抽出する方法は, カメラ撮 影, ビデオプリンタによるハードコピー, 電子変換の 3 種に大別できるが, 画質や処理時間のネックを解消 するため, 電子変換システムによる画像処理や工程の 自動化などの研究開発が進んでいる。

\section{2. 掲 載 状 況}

日常的にはテレビ画像を揭載することは少ないが， 五輪開催中は取材体勢や降版時間との関係上特に多 い. 表 1 はソウル五輪期間中, 新聞各社がテレビ画像 
表 1 ソウル五輪期間中新聞各社がテレビ画面から掲 載した回数と使用機器（新聞協会調べ）

\begin{tabular}{|c|c|c|c|}
\hline & \multirow{2}{*}{$\begin{array}{l}\text { ハイビジョ } \\
\text { ン掲載数 }\end{array}$} & \multicolumn{2}{|r|}{ テレビ画像 } \\
\hline & & 掲載数 & 抽出方法 \\
\hline 朝日 & 2 & 15 & $\begin{array}{l}\text { ソニービデオプリンタ } \\
\text { サカタインクシステム } \\
\text { コニカビデオシステム }\end{array}$ \\
\hline 毎日 & 8 & 1 & ソニービデオプリンタ \\
\hline 読売 & & 15 & $\begin{array}{l}\text { インスタントカメラ } \\
\text { ソニービデオプリンタ }\end{array}$ \\
\hline 産経 & & 3 & 池上 VP-8 \\
\hline 報知 & & 3 & ビデオプリンタ \\
\hline 日刊ス & & 1 & カメラ撮影 \\
\hline 共同 & 4 & 1 & NEC VP-150 \\
\hline 時事 & 2 & 1 & カメラ撮影 \\
\hline 道新 & . & 16 & ソニービデオプリンタ \\
\hline 河北 & & 9 & ピクトログラフィ \\
\hline 信毎 & & 1 & ポラロイド \\
\hline 中日 & & 6 & 池上 VPC-1000 \\
\hline 東京 & 1 & 15 & ビデオプリンタ \\
\hline 京都 & & 1 & 三菱 VDCP \\
\hline 中国 & & 2 & ビデオプリンタ \\
\hline 西日本 & & 4 & ソニービデオプリンタ \\
\hline 佐賀 & & 1 & カメラ撮影 \\
\hline
\end{tabular}

から抽出し, 紙面に揭載した状況と, 使用している機 器の一覧であるが, 写真担当者が実際に画面からハー ドコピーした枚数はその数十倍, 約 200 枚のケースも ある. 雑誌の例では朝日出版社の月刊誌 “English Express” 2 月号は，全体の 65\%，104枚の写真をテ レビ画面から掲載している.

\section{3. 抽出方法と兴の特徵}

カメラ撮影は操作は簡単であるが，走査線が目だ つ，フィルム現像など水処理工程があり，またハード コピーから $\mathrm{C}, \mathrm{M}, \mathrm{Y}, \mathrm{Bk}$ の 4 色をスキャン入力す る工程に約 40 分ほど要する.

ビデオプリンタ使用の場合 $S / N$ には強いが，ハー ドコピーからの処理に同様の難点がある．新聞の降版 直前は寸刻を競う貴重な時間である．以上 2 種の短所 を改善するため, テレビ映像信号を静止画に電子変換 し色補正, 補完, 輪郭強調など種々の画像処理を瞬時 に行うシステムを実用化している。

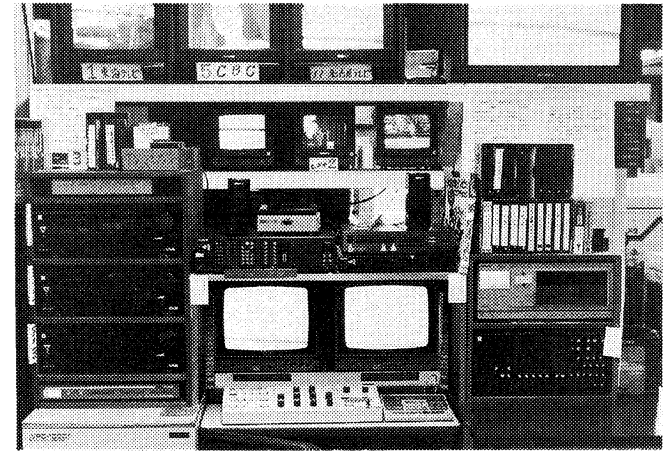

写真 1 中日新聞社のテレビ画像抽出装置

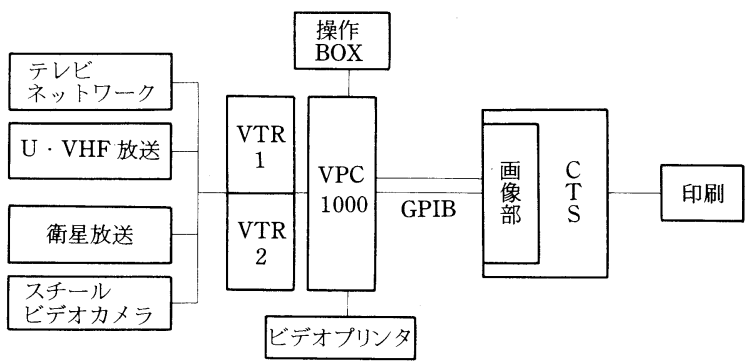

図 1 テレビ画像の電子変換システム理想構成図

\section{4. 電子変換システム}

図 1 の構成図は入力部が産経新聞社，池上通信機の VPC-1000 を使用したホスト部と，出力部が中日新聞 社の例を合成した理想図である。

\section{1 入力部}

系列局国内外 15 チャンネルのテレビネットワーク， $\mathrm{U} \cdot \mathrm{VHF}$ 放送, 衛星放送, スチルビデオ，ビデオテー プなど種々の映像情報入力を可能にしている．2 台の VTR は一方で録画，他方で抽出操作を同時に行う.

\section{2 ホスト部}

テレビ映像信号をディジタル変換し，フレームメモ リーにフリーズする。メモリーは 4 フレームの容量が ある.フリーズはフレーム, ODD ィィールド, EVEN フィールドを被写体の動きに応じて選択でき る. 量子化は 8 ビット, フリーズ後は R, G, B 各々 $\pm 20 \%$ 連続可変でコントラスト, ブライトネスの色調 整, 水平垂直各 5 ステップ $6 \mathrm{~dB}$ の輪郭強調, 525 本 の走查線を 1050 本に補完などの機能がある.

操作はすべて CRT モニタを見ながら操作 BOX の ワンタッチボタンで行う，その他，フィルム感光や八 ードコピー出力ができる.

\section{3 出力部}

量子化したフレームメモリー内の画情報を新聞写真 
にするため, 光の 3 原色 $\mathrm{R}, \mathrm{G}, \mathrm{B}$ をインクの 3 原色 $\mathrm{C}, \mathrm{M}, \mathrm{Y}$ に変換する. ホストと CTS 間は光ケーブ ルで結ばれ, GPIBによる高速転送を行う，CTS 画 像部はシャープネス, 階調補正, トリミング, 拡大, 縮小など種々の画像処理により画質を改善する. 画像 入力から紙面制作までの工程は完全なペーパレスであ る。

ホストから写真受信機, または写真ディジタルシス テムに出力する一般社の場合は, 水平・垂直の画素数 を新聞規格に協動係数変換（縦横の比が画面と同一に なるよう，走査線を補完）する必要がある.

\section{5.むすび}

テレビ画像の最大の難点は画質で, 第一の要因は解 像度である. 新聞写真の標準画素数は通信社系と全国 紙系, 国際規格とでは, それぞれ多少の差異はある が, 主走査が 10 画素/mm (2000 画素/ライン), 副走 査が 4.7 ライン $/ \mathrm{mm}$ で, キャビネサイズ画面当たり 約 120 万画素, 階調は濃度域 0 2.0 (8ビットで量子 化, 256 階調)に対し, テレビ画像の解像度は画素数 が $1 / 4$, 階調 $0 \sim 1.3$ 程度と少ない.

\section{4-4 放 送}

\section{1.まえがき}

テレビ信号は, 画質, 方式・規格の明確さ, 映像機 材の完成度など, 画像信号として使いやすい特性を持 つている.そして, 放送番組やVTRのようなパッケ ージなどから豊富に得られ, ハードコピーの素材とし ても極めて有利である。これらから作成したハードコ ピーはビデオハードコピーと呼ばれ, 放送の静止画応 用の重要なひとつとなっている.

ビデオハードコピーは，画像を見るために特別な装 置がいらず，いつでもどこでも手軽に見ることができ るという, ディスプレイに比べて優れた特長を持って いる.この特長を生かして, 並べて比較したり, 保存

$\dagger$ NHK 放送技術研究所

"4-4 Application of Hardcopy for Broadcasting" by Haruo Okuda (NHK Science and Technical Research Laboratories, Tokyo)
特に動きのある画像はフィールド間にずれがあるた め,フレームフリーズは不適当で, フィールド画にな る。したがって解像度はさらに悪く, ほとんどの場合 アップものに限定される。

第二は録画テープによる劣化が考えられる.テレビ 画面上では特に遜色を感じられない場合でも, 生放送 と録画編集されたテレビ画像の静止画を比較すると画 質の優劣は顕著である.

第三は電波伝搬上の障害である.ノイズの混入, 反 射による二重像などがあげられる。

しかし強力な取材網とネットワーク, 微妙な一瞬を 捕えるテレビ画像の魅力は, 敏腕カメラマンのシャッ 夕をしても及ばない。画質の課題はハイビジョンの早 期普及を期待したい.

(1989 年 6 月 22 日受付)

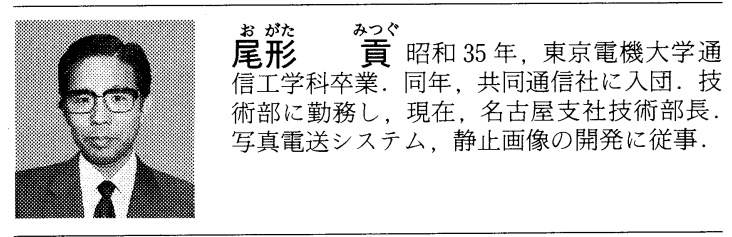

正会員 奥 田 治 雄 $^{\dagger}$

用・広報用資料として使われたり, 印刷用の写真原稿 などとして広く用いられている。また, 番組制作にお いて被写体としても利用される。

ビデオハードコピーの応用は, これまで, 画像の質 よりも内容の方がより重要視されてきた。 ハイビジョ ンの開発が進み，画質が写真に近づいたことにより， 用途がますます広がっている.

ここでは, ビデオハードコピーの特性と, その応用 例である印刷や番組制作などでの使われ方について述 べる。

\section{2. テレビ信号とビデオハードコピー}

\section{1 ビデオハードコピー作成システム}

ハードコピーは画像情報の取込み, 処理, 出力の 3 つの過程により作成される. ビデオハードコピーにお けるシステムの構成を図 1 に示す. 通常, 我々が得る 